\title{
“A MULHER E A ARTE” E A CRÍTICA FEMINISTA DE JÚLIA LOPES DE ALMEIDA
}

\author{
"A mulher e a arte" and Júlia Lopes de Almeida's \\ feminist approach \\ Luzia Margareth Rago* \\ Gabriela Simonetti Trevisan*
}

O talento não tem sexo, defende Júlia Lopes de Almeida, embora o mundo insista em vesti-lo de calças. Escritora de sucesso em sua época, ela acreditava na existência de uma desigualdade entre homens e mulheres no mundo das artes: para elas conseguirem na área a mesma posição que eles, deviam fazer o décuplo de esforço. Contudo ela observa que os tempos mudavam e, com ele, as mulheres cada vez mais se faziam presentes na literatura, na pintura, no teatro e na música. A arte se feminizava.

É essa a ideia que Júlia defende em "A mulher e a arte" conferência datilografada em 16 folhas de papel, pertencente ao acervo da autora na Academia Brasileira de Letras $^{1}$-, texto pouco conhecido e publicado nesta ocasião, na íntrega, pela primeira vez. O escrito pensa sobre os incômodos e desafios das mulheres diante de um mundo que as nega o lugar da criação artística, mas também trata

\footnotetext{
* Professora titular do Departamento de História do IFCH da Universidade Estadual de Campinas (Unicamp). E-mail: ragomargareth@gmail.com

* Mestranda em História Cultural pela Universidade Estadual de Campinas (Unicamp) e bolsista da Fundação de Amparo à Pesquisa do Estado de São Paulo (Fapesp). E-mail: trevisan.gabriela@gmail.com.

${ }^{1}$ Parte do acervo atual foi doada à Academia Brasileira de Letras, no Rio de Janeiro, pelo neto da escritora, Claudio Lopes de Almeida, em 2010. O acervo integra o conjunto de documentos de Filinto de Almeida, marido de Júlia e fundador da ABL.
} 
de suas conquistas e reconhecimentos públicos, que se tornavam cada vez mais frequentes.

Júlia era uma autora que se destacava no mundo das artes entre o final do século XIX e o início do século XX. Aos 19 anos de idade, em 1881, após o pai descobrir que escrevia escondida, é incentivada por ele a publicar pela primeira vez na Gazeta de Campinas, periódico do interior de São Paulo, onde morou durante sua juventude. A carreira como literata deslanchou: publicou quase 40 obras de diversos gêneros literários, contribuiu em diversos jornais de grande circulação da época, como $O$ País, onde manteve uma coluna por décadas, e escreveu em jornais feministas, como A família, de Josephina Álvares de Azevedo ${ }^{2}$. Preocupada com as questões políticas e sociais de sua época, Júlia tratou sobre o mundo rural e também sobre os processos de urbanização que ocorriam naquele momento, assim como sobre as mudanças culturais em meio à consolidação da República.

Os espaços das mulheres na sociedade e o feminismo também marcaram sua vida, em especial, a questão da defesa da educação feminina, mas também do divórcio e do sufrágio universal. Muitas vezes vivendo entre a imagem da mãe e da literata, Júlia inseriu-se no campo masculino da literatura, encontrando respaldo de seus pares (LUCA, 1999). Organizou-se ao lado de militantes como Bertha Lutz e representou a Federação Brasileira pelo Progresso Feminino $^{3}$ em eventos nacionais e internacionais. Suas viagens a eventos e conferências eram frequentemente anunciadas nos periódicos, bem como suas publicações e republicações.

Em suas obras literárias, as mulheres são personagens de destaque e protagonizam situações de amizade, nas quais é comum a reconstrução da vida a partir de uma coletividade feminina (TELLES, 2012). Seus escritos também lançam críticas ao casamento e à maternidade e expõem outras formas de existir enquanto mulher.

2 Josephina Álvares de Azevedo foi fundadora do jornal A Família: jornal litterario dedicado à educação da mãe de família, periódico feminista publicado entre 1888 e 1897 . Primeiramente com sede em São Paulo e, depois, no Rio de Janeiro, tinha contribuição de diversas escritoras, como Júlia Cortines, Ignez Sabino e a própria Júlia Lopes de Almeida.

${ }^{3}$ A Federação Brasileira pelo Progresso Feminino teria sido fundada em 1922, sob a presidência da feminista Bertha Lutz, bióloga e sufragista brasileira. 
Contrariando os discursos médicos normativos da época, que "prescreve[m] papeis sociais muito distintos para homens e mulheres" a partir da biologia (ROHDEN, 2002: p. 115), as personagens femininas de Júlia raramente correspondem à figura da dona de casa $\mathrm{e}$ mãe exemplar, recatada e abnegada.

Em "A mulher e a arte", por exemplo, Júlia apresenta ao leitor um espaço outro que cada vez mais passava a ser ocupado pelas mulheres, isto é, o das artes. Texto sem data, estima-se que tenha sido escrito entre 1926 e 1934, ano de sua morte, uma vez que, segundo Eliane T. A. Campello, uma das literatas listadas pela autora, Grazia Deledda $^{4}$, é citada como ganhadora do prêmio Nobel de Literatura, concedido a ela em 1926 (CAMPELLO, 2007: p. 1).

Contudo a primeira ocorrência no periódico $O$ País de uma conferência de Júlia com esse título é de 10 de agosto de 1906, no Instituto Nacional de Música. Também surgem outras referências a palestras de mesmo nome em 1916, na Escola de Belas Artes do Rio de Janeiro, e em 1918, em uma viagem pelo Rio Grande do Sul, na qual, além de Porto Alegre, a autora teria passado pelo interior do estado. A última ocorrência é de 1919, na ocasião da Exposição de Arte Feminina, em benefício da Casa de Santa Ignes, instituição filantrópica fundada por Mary Sayão Pessoa, esposa do então presidente Epitácio Pessoa.

Não foram encontradas ocorrências n'O País de conferências desse título feitas por Júlia entre as décadas de 1920 e 1930, ainda que o texto traga referências a fatos dessa época. Também não há notícia de publicação desses textos ou presença de qualquer outro documento intitulado "A mulher e a arte" no acervo da escritora, o que permitiria observar os conteúdos dessas palestras. Contudo destaca-se o fato de que, pelo menos desde 1906 e até a fase final de sua carreira, a literata preocupou-se com a temática das mulheres no mundo da criação artística, assinalando as desigualdades entre os sexos.

Do outro lado do oceano, em 1929, a escritora inglesa Virginia Woolf publicaria Um teto todo seu, uma reflexão baseada em

\footnotetext{
${ }^{4}$ Grazia Cosima Deledda (1871-1936) foi uma escritora italiana que recebeu o prêmio Nobel de Literatura pela obra Canne al vento (1913), em 1926.
} 
conferências dadas pela autora também sobre a temática das mulheres no mundo da arte. Segundo ela, em uma aproximação possível com o texto de Júlia, "em todos esses séculos, as mulheres têm servido de espelhos dotados do mágico e delicioso poder de refletir a figura do homem com o dobro de seu tamanho natural" (WOOLF, 1990: p. 48). Para Woolf, o pensamento e a escrita foram historicamente atribuídos aos homens e afastados das mulheres, ideia reforçada pela emergência da ciência, criando uma série de interjeições às iniciativas artísticas femininas. Ácida, ela denuncia como o sonho de viver da arte, para as mulheres, foi quase sempre relegado à morte.

Também muito crítica, Júlia ressalta a postura patriarcal dos homens diante das artes femininas, colocando-se sempre como desconfiados. Contudo a autora busca destacar os inúmeros nomes de escritoras, pintoras, escultoras, atrizes e músicas que já possuíam grande fama e recebiam até mesmo premiações. Segundo ela, se o talento feminino foi, por muito tempo, desprezado, ele era finalmente reconhecido, e o espaço das mulheres na arte se estabelecia, constituindo um processo que não poderia mais ser contido. Dessa forma, Júlia Lopes de Almeida denuncia a cultura patriarcal, não sem também trazer à tona uma feminização da cultura que cada vez mais se consolidava, construindo seus pilares sobre uma crítica e uma poética feminista.

\section{Referências bibliográficas}

CAMPELLO, Eliane T. A. ““A mulher e a arte', na visão de Júlia Lopes de Almeida". In: Anais do XII Seminário Nacional Mulher e Literatura e do III Seminário Internacional Mulher e Literatura, 2007, Ilhéus. Disponível em: http://www.uesc.br/seminariomulher/anais/PDF/ELIANE\%20TEREZ INHA\%20DO\%20AMARAL\%20CAMPELLO.pdf. Acesso em 14 out 2018.

LUCA, Leonora de. "O 'feminismo possível' de Júlia Lopes de Almeida (1862-1934)". Cadernos Pagu. Campinas, n 12, 1999. Pp. 275-299.

O PAÍS. Rio de Janeiro: Hemeroteca Digital (Biblioteca Nacional), 1884-1930. 
ROHDEN, Fabíola. "Ginecologia, gênero e sexualidade na ciência do século XIX”. Horizontes Antropológicos Porto Alegre, 2002, ano 8, $\mathrm{n}^{\mathrm{o}}$ 17. Pp. 101-125.

TELLES, Norma. Encantações: escritoras e imaginação literária no Brasil, século XIX. São Paulo: Intermeios, 2012.

WOOLF, Virginia. Um teto todo seu. São Paulo: Círculo do Livro, 1990. Tradução de Vera Ribeiro 



\title{
A MULHER E A ARTE ${ }^{1}$
}

\author{
Júlia Lopes de Almeida
}

Por mais imperiosa que seja a vocação das mulheres na arte, quando a professam ficam quasi sempre em meio do caminho. Aos nomes rutilantes de uma Vigée-Lebrun, de uma Rose Bonheur, de uma George Sand, ou Mm. Acherman, Ada Negri, Grazia Deleda, Selma Lôngerloff e poucos mais, faz fundo uma onda imensa de outros nomes representativos de merecimentos verdadeiros e de tenazes esforços, mas que não chegaram nunca a atingir o zenith da arte e raramente alcançaram mesmo nivelar-se aos maiores artistas masculinos seus contemporâneos. O excesso da emotividade na mulher, as contingências físicas do seu organismo, o sentimento pertubador da maternidade, cujos instintos se anunciam nela desde criança, e, mais do que tudo, a sua falta de instrução e de liberdade, opõem-se a que o seu vôo se desprenda com ímpeto e as arrebate até á altura das suas aspirações. Para uma mulher conseguir em arte metade do que consegue um homem, de igual talento e de igual vontade, tem que despender o décuplo do esforço, não só porque o mundo preparou melhor a competência masculina desenvolvendo-lhe progressivamente e constantemente a inteligência, como também porque ele conta com maior simpatia das populações e o estímulo sugestivo dessa predisposição - é também uma força!

Nenhuma mulher ignora as desvantagens que lhe cabem por sorte na ingrata luta mas também nenhuma a evita, porque não entra

\footnotetext{
${ }^{1} \mathrm{O}$ texto foi transcrito a partir do documento datilografado, encontrado no acervo de Júlia Lopes de Almeida, na Academia Brasileira de Letras. Pensando o texto como fonte histórica, optouse por manter a grafia da escritora para as palavras, marcada pela escrita da época e pela influência do português europeu, assim como pelo seu amplo conhecimento de outros idiomas, como o francês. Dessa forma, foram alterados apenas erros tipográficos que comprometessem a compreensão do texto, como palavras sem separação por espaço ou o uso de algumas acentuações.
} 
nela por fantasia nem por vaidade, mas por um pendor irresistivel da sua natureza, o mesmo pendor que impele muitos homens a escolher a carreira artistica entre todas as outras que a sociedade lhe oferece, embora convencidos de que nela a vida lhes será muito mais dificil e muito mais precária. São esses sacrifícios que a arte traduz em esplendor para a patria e para o mundo.

Até ha pouco anos ainda, as mulheres acobardadas por essa espécie de hostilidade, entravam em número muito restricto para os campos da Literatura ou das artes plasticas, e ainda valendo-se frequentemente de pseudónimos masculinos que lhe garantiam a tranquilidade dos primeiros tempos de trabalho e lhes facilitava a conquista do público. Hoje o número das mulheres artistas se não é infinito é pelo menos enorme. As escultoras, as pintoras, as escritoras, já não são olhadas pelos homens com um levantar de ombros que signifique - paciencia! - em face da obstinação. Elas ocupam um lugar ao lado deles nas estantes das bibliotecas e nas paredes dos museus, são coroadas pelas academias, são disputadas pelos editores, são premiadas pelos juris das exposições. Não foi já concedido a duas mulheres ilustres, Selma Langerloff e Grazia Deledda o grande prémio Nobel? É evidente que nem estas escritoras nem todas as outras que de algum modo tenham recebido manifestações de apreço, quer das academias quer dos governos dos seus respectivos paises, como muitas da França condecoradas com a Legião de Honra, foram agraciadas pelo simples motivo de serem senhoras, mas por que não lhes puderam negar o que elas conquistaram á força de talento, que não tem sexo, embora o mundo teime em vesti-lo de calças quando o quer adular! $\mathrm{O}$ das mulheres, como disse o poeta Castilho, -foi atirado para a roda dos engeitados... mas da roda ou do cárcere, quando tenha nascido com o filão luminoso do sonho, ele desertará cedo ou tarde, torcendo frades ou arrancando fechaduras.

Tudo se pode escravisar no mundo, menos o pensamento.

Para símbolo desta anciedade, deste desejo de realisação de um ideal, existe na historia contemporânea uma admiravel figura feminina: - Maria Barshkirtsef.

Era russa, linda, rica e filha de pais nobres. Aos cinco anos coroava-se de flores, enfeitava-se com as rendas maternas e ia inventar danças e fazer atitudes nos tapetes do salão ou nos relvados 
do jardim. Já na sua inconsciência infantil germinava o sentimento da harmonia, a beleza do rítmo que rege o movimento universal.

Era a arte do gesto de Isadora Dundan que extraordinário instinto da pequenina russa realisava num encantador esboço, com as suas perninhas gordas de bebê e os seus braços de anjo de Murilo. Os convidados batiam palmas e a família gosava a delicia daqueles quadros expontâneos em que latejava já a aspiração que fez mais tarde a pobre Maria delirar de goso e de sofrimento... Com o correr dos dias mudaram-se as suas tendencias. No raiar da adolescencia, indo passar uma temporada em Nice, expressava a sua emoção cantando em frente ao mar árias que inventava no momento. As ondas morriam-lhe aos pés com sonoridades de ovações, que lhe acendiam a ideia dos aplausos das grandes plateias mundiais. Foi assim que percebeu ter uma linda voz e que pensou em se fazer artista lírica. $\mathrm{O}$ teatro começou desde logo a ser a sua obsessão. Na idade em que a menina pensa ainda na sua última boneca e já no primeiro namorado, concentrava Maria todo o seu desejo nas glórias do palco. Percebia que não tinha nascido para mediocridade e que o seu talento a levaria longe. Estudava com entusiasmo frenético, os seus progressos se precipitavam com tal furia que ainda era uma criança e já estava prestes a entrar para o teatro, não como principiante, mas como artista digna da celebridade. Foi então que por um frio inverno ela ensurdeceu e perdeu a voz... As lágrimas de desespero que chorou, não lhe apagaram a chama da inspiração nem o seu amor cada vez mais absorvente pela arte. Não poderia cantar, comover as multidões com o som purissimo da sua voz? Procuraria na pintura o que não tinha conseguido na música, um desabafo para o tumult das suas sensações espirituais. Parte para Paris e, ao mesmo tempo que escreve o seu jornal, que é um dos mais belos documentos humanos até agora conhecidos, matricula-se numa escola de desenho e trabalha, e trabalha, e trabalha com o mesmo desespero com que estudara o canto. Avança aos saltos; dirige ela propria as suas disciplinas. Em todo o seu curso não copiou um só gesso. Quer, desde os primeiros passos conhecer a vida e a verdade.

Em plena mocidade, formosa, rica, ambiciosa de renome e de glórias, no momento mesmo em que sentia voltar-se para ela a atenção do público, morre. Morre aos vinte e dois anos... 
Na persuasão de que só com uma dedicação esclusiva se pode ser grande em arte, Maria professara a sua como uma freira professa o veu de religiosa, mas o destino fechou-lhe rudemente a porta do templo no proprio instante em que a viu pisar a pedra da soleira.

As mulheres que não renunciam á sua parte de gozo ou de sofrimento no amor; ao que se enredam nas teias da familia, - ou andam muito devagar na arte, ou não caminham de todo, a não ser que tenham génio; mas o proprio genio está sujeito á dôr das contingencias.

Por seu lado o povo manifesta muito maior e mais visivel interesse pela artista que interpreta do que pela que compõe. Essa preferência consiste na comunicação directa do sentimento dela com o seu. Ele vê assim completados pelos sentidos da vista e do ouvido as sensações que lhe sugerem a musica e o pensamento do maestro ou do escritor invisivel. A turba é preguiçosa, dir-se hia que não sabe ir sosinha ao encontro da arte, precisa muitas vezes de interpretes que lha façam sentir, e é a eles que destina o mais quente dos seus aplausos.

Vão felizmente recuando os dias em que as mulheres consideravam as artes meras prendas de salão, exercidas nas horas fugivas da mocidade e abandonadas logo que os dias estaveis começavam a ser vividos. Desde que tivesse produsido o seu efeito de conquista a pobre arte era abandonada como um adorno desnecessario e de dificil conservação. Em geral não se estudava pintura, música ou declamação por amor á arte, mas por amor proprio, e a mulher dedicava por isso ás coisas do pensamento uma atenção vaga e distraida. A educação feminina mudou de repente. E ela hoje encara o estudo com seriedade, chegou á compreensão de que arte não é aparato, não é brinquedo, não é luxo só para os momentos efêmeros da sociedade, mas outra cousa bem poderosa, bastante forte para encher uma existencia inteira, consola-la nos dias de amargura, fazela irradiar nos de felicidade. Mesmo assim ainda não se olha com extremos de simpatia para a mulher artista de quem se acha sempre prudente desconfiar um pouco... Ela porem parece, ou finge parecer não dar por tal, e continua o seu caminho, estrada de Damasco ou estrada do inferno, absorvida por pensamentos em que a sua individualidade não toma vulto. Impressionavel, vibratil, instrumento 
repercussor de todos os fenómenos da natureza, não passa pela vida como em geral todas as outras mulheres, como quem atravessa um corredor de porta a porta entre espelhos, em que só a sua imagem se reflete. Não; para o goso da sua admiração não ha no mundo coisas vãs nem insignificantes. Onde haja.. o quê? vê-de: uma flor ou um pequeno insecto, ha uma vida e um mistério que a comovem; onde se rasgue uma acção nobre, ha um respeito que a submete a uma admiração feliz. A arte apura na mulher as suas qualidades sensitivas, é o cadinho em que se fundem os seus instintos desordenados. São esses instintos que a tornam de algum modo incompreendida, como filha de uma outra raça, á qual nada se deve perdoar. Do que ninguem se lembra é que o seu maior mal é de estar sempre em foco diante da lente do observador, esse olho intolerante, mais inquisidor do que analista, em que os defeitos alheios aumentam sempre de proporção. É por isso que público em geral a teme e teme principalmente a escritora, cuja psicologia julgam muito complicada e cuja linguagem pensam dever ser sempre erriçada de termos preciosos de citações eruditas.

Compreende-se que a presença de tais criaturas se pudesse causar embaraços e fazer aflição. Ir uma pessoa desabafar os seus queixumes no seio de outra e ouvir em resposta elogios aos mármores atenienses, lamentar-se de desgostos, e recitarem-lhe á guisa de consolação verso camoneanos; querer combinar um modo prático de pôr cobro á impetuosidade das suas despesas domésticas, e descreverem-lhe em resposta as festas dionísias... seria para desorientar a própria bussola; mas tal não se dá nunca, a não ser quando se trate, não de uma artista verdadeira, mas de uma pedante, destas que ainda aparecem, mas cada vez mais raramente, tanto na sociedade das outras como naquela a que se convenciou chamar - das bas-bleus.

E aqui está uma designação que por muito tempo foi aplicada como ridiculo á mulher de letras que é, não sei porque, a mais satirisada dentre todas as artistas femininas. Esta expressão antipatica é de origem inglesa. É a fiel tradução de blue-stockings. Em fins do século XVIII havia na Inglaterra uma escritora que reunia uma vez por semana em seus salões uma certa roda de amigos e de amigas dos mesmos gostos literários. Frequentava essa casa um tal Snr. Stilling Fleet, que tinha a mania de só usar meias azuis. Não é absurdo; em 
todas as épocas e em todas os paises ha homens que se obstinam em só usar uma certa e determinada moda fazendo consistir nessa extravagancia toda a sua originalidade. Mas as rivais da escritora e das suas amigas não entenderam assim e aproveitaram a esquisitice desse tal Mr. Steeling Fleet, cujo nome já parece um assobio de vaia, para apelidarem as reuniões para que não eram convidadas com o título de - Circolo Bas Bleus - Como se vé esse epigrama nasceu não do ridiculo de uns, mas do despeito de outros, e foir por muito tempo usado em sentido pejorativo. Dele se livraram as pintoras, as compositoras, as escultoras e todas as mulheres que se dedicam á sciencia: médicas, farmaceuticas, professoras, mas não as escritoras. Porquê?

Toda a mulher pode ser melhor ou pior, conforme um capricho da natureza ou um vicio da educação, mas não será a arte que esterelise o que houver de sinceridade e de bondade em sua alma, por que antes pelo contrario, a arte aperfeiçoa, não perverte ninguem. Argumentareis com os perigos da imaginação. Realmente são terriveis, mas esses não são adqueridos na profissão, são um mal de nascença, um mal ou um bem, para o qual ainda assim ela tem uma disciplina: o trabalho, o trabalho que extenua porque mina e mineiro a um tempo todo o artista que produz arranca do coração e do cerebro pedaços de vida que dispersa aos quatro ventos, como a árvore deixa voar as folhas dos seus ramos. Que importa aos outros o que isso custa? Ninguem sabe se a arvore sofre ao desnudar-se, o que nos faz voltar a cabeça num movimento de fugitiva atenção é ver se no redemoinho dos ares essas folhas procuraram avisinhar-se do ceu ou se rastejam na poeira do chão. Aos olhos da sociedade a escritora mais do que qualquer outra artista tem de ser responsavel pela mulher. É por essa falta de liberdade que a maior parte se sujeita a engrinaldar de florinhas de papel, períodos a que só falta o adubo da franqueza para o desabrochamento de rutilantes girasois... Sem sinceridade não ha artista digno desse nome. Foi aludindo a esse recato que Mdme. De Staél escreveu: -"Por une femme la gloire est le deuil eclatant du bonheur!" Como ela não tem culpa de ter vindo ao mundo com essas semesntinhas d'oiro no cérebro de que germina a fantasia, quiz o destino misericordioso que ao lado desse luto, dessa forca da felicidade, desabrochasse a flor divina das compensações. A febre de produsir, de poder sucessivamente crear um filho da sua 
carne e um filho do seu sonho, fazer o homem e criar a ficção, desfraldando a bandeira da patria duas veses, no culto da família e no da arte, é uma sensação nobre e que oferece á consciencia da mulher uma tranquilidade perfeita. Por mim não a lamento. Todo o espirito creador deve sentir espalmada sobre si a luminosa mão de Deus. Na tela, no marmore ou no livro essa benção de luz transparece, quer neles resplandeça a nudez da verdade quer a fluidez do sonho... Infelizmente para se viajar por esse doce país da arte não basta o bordão florido da imaginação nem as sandálias do peregrino pobre; é preciso uma grande coragem, uma fé instinguivel, uma vontade de ferro de caminhar, caminhar sempre com os olhos no seu ideal, porque ideal não é devaneio, é um fito, é uma estrela que preside a um destino, e que tem voz.

\section{-O teu caminho é este, vem!}

E o artista tropeçando em dificuldades ou correndo sem peias obedece-lhe para andar a vida toda, que os caminhos do ideal são infinitos...

É teoria corrente que entre mulheres só pode haver uma desigualdade: a da beleza. Ser bonita ou ser feia, eis a questão. Ora o dom da formosura parece estar averiguado raramente caber á intelectual. Dir-se hia que a prodigalidade da natureza é calculada e as suas distribuições equitativas. Notou alguem que no teatro as grandes as maiores artistas são quasi sempre mais feias do que as comprimárias. As suas faces agitadas não teem a frescura doce á vista; os traços são quasi sempre irregulares, os cabelos rebeldes, a boca rasgada para que as expressões possam jorrar por ela em ondas sonoras. Mas reparae bem que, se falta perfeição a esses perfis e linhas de estética rigorosa aos teus corpos, elas teem em compensação um fulgor que as ilumina, qualquer coisa que vem das estrelas d'alma, para reger-lhe o gesto que é bem feminino, poderosamente feminino, sendo também por vezes bem diabólico. Ha uma circunstancia, ainda que faz com que as grandes artistas dramaticas pareçam sempre menos bonitas do que as insignificantes, é que elas só começam a ser verdadeiramente senhoras da sua arte quando a sua mocidde começa a desaparecer. Essa injustiça da natureza em nenhuma mulher se faz 
sentir com tamanha impiedade como na artista de teatro; creadora da ilusão.

Não ha mulheres tão dessimilhantes entre si como as que se dedicam á arte, seja ela qual fôr e as que se dedicam á sciencia, seja ela qual for tambem. A estas os estudos positivos bem determinados, dão-lhes um ar tranquilo, A sua presença inspira por força maior confiança porque ela é mais calma e mais simples e a singeleza foi toda a vida o segredo do agrado. Não a julguemos por isso menos sensivel que a maioria das outras mulheres. Heloisa sabia latim, grego, hebraico, astronomia, filosofia, e, como toda a gente sabe encerrou-se num convento por desgostos de amor. A mulher artista é mais perturbadora; especie de interrogação viva que não renega, antes requinta as qualidades do seu sexo, amigo de elegancias, por que ao contrario do que muita gente pensa não ha mulher mais feminina do que ela em contraste com a do povo, que é mais povo que mulher, conforme a observação de um escritor francez.

Ha um qualidade pouco reconhecida e entretanto muito vulgar nas artistas: a bondade. Georje Sand, a fraseologista ardente, a vigorosa fabricadora de almas, repartia com os aflitos tudo que lhe davam os seus livros e era chamada pelos camponeses de uma terreola a que costumava ir: la bonne dame. Porquê? porque ao inverso das burguesas de Paris, que achariam isso ridiculo, ela parava na estrada conversando com a gente rude, sorrindo ás suas afirmações, estremecendo ás suas desventuras. Que sabiam dela os camponeses? Nada; nem o seu nome, nem os seus triunfos nem os seus amores. La bonne dame, era a designação suficiente para a destacarem da sociedade que passava por eles sem os ver... É que a escritora respeitava em cada individuo a humanidade que ela amava e reproduzia nos seus romances. Não via em todas as classes superiores nem inferiores; via homens, o sofrimento, a vida!

Talento! Quasi todas as mulheres o maldizem como fonte de amargas decepções. Suponho entretanto que se o talento fosse coisa possivel de ser arrebatada por mão alheia todas o defenderiam da melhor forma que pudessem. Se é verdade que a sensibilidade mais afinada dessas mulheres as fazem sofrer mais profundamente a dor, naão as fará tambem sentir mais jubilosamente a felicidade? Não teem todos por acaso no mundo o seu quinhão de sofrimento? A arte ainda assim pode servir de lenitivo a muito dissaber, de esteio a 
muitas fraquesas! Seria levar muito longe a magia da sua influência o imaginar-mos que ela possa servir de consolo para tudo!

A poetisa grega aperfeiçoadora da técnica do verso, creadora da Escola de Lesbos, cujo nome atravessa os séculos como uma seta de ouro, essa tempestuosa Safo, trigueira, magra, pequenina, de quem entretanto disse um poeta "ela é bela como a tempestade é bela, com as suas cóleras, seus gritos, suas avalanches e seus relampagos"; Safo, chama de sensualidades brutais, e de idealidades divinas, exilada da sua terra, repudiava no seu amor, precipitando-se de um rochedo no mar profundo, ela a quem os poetas teciam inos, e o povo oferecia palmas, não indica bem que não basta a glória nem a arte para a felicidade da mulher, nem de ninguem?

Menos exaltadas, as artistas de hoje, Deus louvado, vivem em melhor paz e entre tanto suicidios que os nossos jornais noticiam frequentemente não vejo nunca um nome de mulher intelectual. Pois não nos faltam poetisas, nem rochedos, nem mar profundo, nem recantos dignos de uma tragedia em que a Morte figure coroada de louros. Por mais cálido e vibratil que seja o temperamento da mulher moderna, ficam-lhe todas as culpas nos desvarios frenéticos do amor de que ela sofre as consequências corajosamente...

$\mathrm{O}$ caso da linda madame de Tencin, escritora francesa do século XVII, abandonando o filho nos degraus de uma catedral é talvez único na galeria das mulheres de letras. O filho vingou-se, tornando-se um dos homens mais celebres do seu tempo, o que agravou por certo a culpa da mãe; $O$ natural é que a observação da vida, a defesa das misérias, a fascinação de tudo que é generoso e belo, excitem a alma para o bem e para a tolerancia. Não me lembra que na galeria dos crimes em que figuram alias tantas mulheres históricas de alta linhagem se conheçam nomes mulheres intelectuais; estas só fazem victimas no amor, dele são víctimas tambem, e quasi sempre as mais sacrificadas. A arte exige grandes devotamentos e estes serão tanto mais proveitosos, quanto menos irregular e dispersiva fôr a vida dos que a sirvam. Só quem trabalha triunfa; só quem se obstina vence.

Tão maravilhosa e irresistivel é a sedução da arte que chegou a fazer com que uma rainha, e nos tempos em que reinar tinha o maior prestigio, renegasse por ela o seu trono. Em plena mocidade, forte e 
querida do seu povo, Cristina da Suécia abdicou da coroa em favor de um parente mandando cunhar para a comemoraão do facto uma medalha com estes dizeres:

"O Parnaso vale mais que o trono".

Não sei se ela deixou obra do valor da renuncia, mas não consta á historia que se tivesse arrependido. Outras rainhas em épocas posteriores, se não trocaram o scetro pelo pincel ou pela pena, fugiam muitas veses das rodas costesãs, para a solidão amiga dos seus ateliers ou de os seus escritorios.

Carmen Silvia, substituindo o manto régio pela tunica de trabalho, limpava as mãos da baba aduladora dos seus subditos para escrever entre ramos de hortencias e cochins de veludo os seus pensamentos trespassados de piedade e de filosofia. A rainha Victoria da Inglaterra, quando se queria aproximar da verdade, fechava-se no seu gabinete a escrever livros. Para eles guardava a sua sinceridade de mulher. A mão gravava o que os lábios não ousavam dizer; e pena é que o exagero das conveniencias não consentisse que esses documentos tivessem chegado ao conhecimento do público. A arte aristocratisa os individuos, as proprias rainhas se requintam com ela. Faz mais: aprimora tanto as qualidades do espirito como as do coração.

Que romancista fez já deslisar tantas lágrimas benéficas como essa clemente Beecher Stow com a sua revoltada Cabana do Pai Tomás? Em face do escravo, a mulher se não egualava, excedia quasi sempre o homem em crueldade e em desprezo. É um facto que desorienta o mais atilado psicólogo e de que infelizmente não podemos negar a veracidade. Beecher Stow, iluminada por um sentimento superior de justiça, encheu o seu livro de clamores e de imprecações e tão estridentes e tão sinceras, que lograram acordar não só no seu paiz como em outros que viviam ainda sob o peso da mesma ignominia uma ideia de altruismo e de reparação. Sob a armadura desse livro de combate palpitava um enternecido coração de mulher, cheio de fé na propria humanidade que ele profligava! Esse mesmo sentimento fazia com que George Elliot considerasse o seu posto de romancista como de um verdadeiro apostolado. O seu sonho era desenvolver a simpatia e a boa vontade entre os homens, torna-los capazes de imaginar e de sentir o mal dos que diferem deles em tudo, menos em serem criaturas humanas. Queria a arte como um 
evangelho. Essa, referindo-se a um dos seus romances, Adam Bed, exclamava num rasgo de júbilo que lhe tinha valido a pena de ter vivido longos anos só para o ter escrito. Dava-se por compensada. A venturosa...

Tivesse eu poder e força evocativa para fazer deslisar diante dos vossos olhos sossegados a longuissima prossição de mulheres artistas de todos os tempos! Iria busca-las pela mão ás lages frias dos conventos, aos salões doirados dos palacios, ou ás humildes cosinhas das aldeias, onde como a mulher de Tomás Carlile, faziam pão nas horas desertas e silenciosas da noite... Se entre elas ha muitas figuras desinteressantes, quantas como essa amorosa anémona que se chamou Mariana Alcoforado ou como a virgem do Carmel, St. Tereza, a quem os papas concederam o titulo de doutor e cujos escritos a Academia Espanhola tem como os mais belos monumentos da lingua castelhana, vos dariam um arrepio de comoção e de interesse!

Um fenómeno curioso que se pode observar em relação ao sentimento e á capacidade da mulher no exercicio das artes é a sua incompetencia para a composição musical. Não me consta que essa anomalia tenha já sido esplicada, nem mesmo notada por ninguem, embora constitua um problema de curiosa decifração. Ele é tanto mais paradoxal quanto a musica é exatamente a arte preferida e a mais cultivada pelas mulheres de todo o mundo. O seu estudo é considerado nas familias desde longos anos como uma espécie de obrigação já tradicional. É mesmo o único, depois dos rudimentos das primeiras letras que é geralmente imposto ás meninas, seja qual fôr a sua situação social. A teoria das correntes atávicas fica desse modo muito comprometida, quando, de mais a mais se sabe que alem de exercer tão grande fascinação sobre o espirito da mulher a musica "que penetra mais do que as artes plasticas na essencia das coisas porque irrompe do seio humano como a expressão da propria dor ou da propria alegria" - melhor do que nenhuma outra arte poderia abrigar o seu recato ou servir de válvula ás expansões das suas emoções mesmo as mais intimas e pessoais. Enquanto na literatura e nas outras artes fulguram belos nomes de mulher, são raros os de maestras que tenham logrado ultrapassar a barreira do seu respectivo país, e esses raros pertencem á França. Como interpretes muitissimas teem chegado á mais alta culminancia, penetrando até no fundo do 
pensamento dos maiores autores, difundindo-lhes pela magia da sua voz ou dos seus dedos as belezas da sua inspiração. Seria uma blasfemia negar-lhes receptividade para as emoções musicais, mas é facto que elas preferem para moldura do seu pemsamento, ao ritmo da musica e do verso, que é de todas as artes a mais cultivada e talvez por isso mesmo, a mais profanada... Ninguem se lembraria nunca de escrever uma pagina musical sem ter aprendido antes a teoria da composição, mas não ha quem não tenha mesmo sem o menor conhecimento das regras de metrificação escrito algumas estrofes em certa hora da vida... Sei que a música e a poesia são manifestações expontâneas da alma popular, mas não é á feição da trova, que algumas ha de beleza peregrina a que me refiro, mas ás poesias cuja forma exige alguma coisa mais do que inspiração e do que boa vontade. Não será por um transbordamento de emoção que em tal ou tal dia um filho de Deus escreve um soneto na persuasão que baste para isso pegar na pena e deixar falar o coração... Não basta; o proprio autor verifica mais tarde a fraqueza ou desarticulação dos seus versos mas raramente os inutilisa, ou porque lhe peie o gesto um certo respeito por aquela loucura passada, ou por que nela tenha cristalisado uma lagrima ou um sorriso da sua vida, a que o verso servio de engaste.

Estremeço á ideia dos milhares de raparigas moças que errem por todo este mundo tateando nas trevas da ignorancia ao mesmo tempo que sentem transluzir no fundo confuso do cerebro a entrelinha magica da inspiração. Resta ás veses um acaso feliz de um momento para esclarecer uma inteligencia, mas o acaso feliz não costuma passear pelo bairros da miseria e é raro assim a pobre que o encontre no seu caminho... Encontrou-o por fortuna sua a pintora Juana Romani. Alta, esbelta com ondulações de sereia no corpo branco, a que uma cabeleira de ouro fulgente punha uma coroa de sol, ela ignorava tanto a sua beleza como o seu talento. Morava numa mansarda, vestia-se de trapos, curtia frio e fome. Foi assim que o escultor Falguiere a viu um dia na rua a tiritar, mal enrolada num chale velho, magra e disfigurada. A sua experiencia fe-lo perceber naquela criatura um modelo magnifico; levou-a para o atelier e copiou-lhe as formas numa das suas estátuas. Sem imaginar, ele fazia ao mesmo tempo duas obras; a da modelagem de uma escultura e a de 
uma revelação. Foi assim que a pobre ignorante, sentiu em todas as parcelas do seu ser a vibração harmoniosa, divina, de uma existencia espiritual de que ela não tivera até então nem mais longinqua ideia... Com os olhos maravilhados pela beleza dos mármores, andando ainda como num deslumbramento, passou Juana a servir de modelo ao pintor Henner. Aí o desejo de fazer arte, de criar tambem maravilhas, a dominou de uma tal maneira que não lhe poude resistir e começou tambem a estudar! A arte faz prodigios, é a verdadeira taumaturga dos tempos modernos.

Veja-se nos quadros: de um trapo velho pendente de uma cerca, agitado pelo vento ou batido pelo sol, faz uma coisa deliciosa que os olhos não se cansam de adimirar; de um pregão de rua aspero ou gutural desenvolve ás vezes harmonias largas; de um velho triste e feio a pender para a morte faz uma estatua eterna...

Por todas as formas por que sirva a arte, a mulher só tem nela supremacia na do teatro. Porquê? Porque no teatro ela é precisa ao homem. Nesse campo ele nem se arreceia da sua concorrencia nem lhe discute a competencia, da-lhe a mão, chama-a a si. É uma igual. Sentindo-se num elemento em que não é considerada como intrusa, a mulher no palco expande-se á vontade e chega a conquistar as mais altas e mais brilhantes posições. Ninguem excedeu a Duse, ninguem excedeu Rejane, ninguem igualou Sara Bernard, que já na idade em que nós outras murchas e moles não pedimos á vida se não um colchão fofo para os ossos e um alimento brando para a boca, trabalhava ainda e dizia com a mesma frescura de memoria dos vinte anos longas tiradas dos escritores do seu país. A vida intelectual é um manancial de primaveras, do teatro não sonhará, mas tendo de incarnar o sonho dos autores adquire alguma cousa de extraordinario, que a torna como que de uma essência diferente da das outras mulheres. Que seria do teatro sem ela? E, tambem: que seria ela em todas as outras artes se encontrasse nelas o apoio que encontra em cena?

Dizem que no Japão o teatro foi destinado exclusivamente ao homem. Só uma artista feminina, Sado Yaco ousou pisar o palco japonez. Ao principio a velha Yedo toda se encolheu e abispinhou contra essa filha revoltosa que Paris representava nos seus cartazes artisticos entre grandes flores de Lotus e sedas matisadas. Mas a renovada Tokio percebeu que a voz daquela mulher revelaria ao 
mundo as glórias e as graças da sua terra e, não só consentio em que ela viajasse como actriz japoneza, como ainda a aplaudiu. Fez bem, porque em boa verdade foi Sada Yaco quem primeiro e melhor revelou o Japão á Europa e conseguintemente a todo o Planeta. A guerra que a celebrisou não teve o mesmo poder de sugestão e de poesia. Os soldados japoneses mataram á europeia, com arte adquirida na imitação, fardados como os soldados do mundo inteiro, com armas como as dos outros exercitos. Ela, vestida á japonesa, calçada á japonesa, falando japonez que ninguem intende, com toda a expressão japonesa, acordou na alma do estrangeiro a sensação esquisita de estar ouvindo o sussuro dos arrozais do Nipon, sentindo o aroma dos seus lírios, d'agua e vendo as copas rosadas das cerejeiras em flor entre cabanas de papel e musumés estaticas rezando á Lua... O estampido dos canhões e o cheiro da polvora não tem tanto poder, ah, não tem. O Japão da guerra é um Japão imitado, o de Sada Yaco, pareça embora profanação, é mas patriotico porque é mais caracteristico e mais nacional. Ela foi a reveladora da arte feminina no palco japonês.

Se em todas as outras artes a mulher salvo raras excepções é geralmente medíocre, na de representar, quando não os excedem caminham perfeitamente ao lado dos artistas masculinos, a razão será talvez esta: que adimitindo o teatro numero de mulheres correspondente ao dos homens elas não se sentem ali isoladas e estrangeiras, e que mesmo por serem muitas há mais probabilidades de ressaltarem entre elas individualidades e aptidões que, sem estudo e sem meio não teriam revelado. Teem o ambiente que falta ás outras mulheres; o público anima-as com a sua simpatia, o seu prestigio que recebem dos autores reveste-se de qualidades excepcionais e esses factores produzem como que uma espécie de corrente elétrica que as ligam aos seus expectadores numa continua vibração. $\mathrm{O}$ acorôçoamento da turma estimula o talento, mesmo o mais modesto, mesmo o mais refractario ao elogio, ou o mais consciente da sua força.

"Le poète qu'on n'ecoute pas finit par se taire" disse a estraordinária Me. Ackerman, esplicando os seus longos silencios entre umas e outras das suas produções. Essa recatava tanto o seu talento, que o seu proprio marido viveu e morreu a seu lado ignorando que ela fizesse os magnificos e profundos versos que fazia. $\mathrm{O}$ 
preconceito que vulgarmente existe contra a mulher de letras fê-la sacrificar o seu esponto, com medo de que o marido deixasse de amala. Ha ainda muitos talentos femininos que o mesmo pavor sufoca ou que a falta de meio propicio deixa na completa ignorancia das suas proprias aptidões.

Foram as retortas, os alambiques todos os aparelhos do gabinete de física de um sábio, russo que predispuseram na filha esse amor da sçiencia que a levou mais tarde a colaborar com o marido em obras de investigação e a descobrir o Radium. Se Mdm. Curie tivesse sido criada longe das preleções e dos devotamentos de um professor, talvez não tivesse chegado a compreender todas as disposições do seu talento e vivesse sofrendo desse mal ignorado, indefinivel, que perturba a alma de todos os predestinados a serem alguem e que não chegam a ser coisa nenhuma.

Se do mesmo modo não tivessem sido criadas a sombra dos ateliers paternos, quem sabe os maravilhosos talentos de Mdm. Vigée Lebrun e de Rose Bonheur teriam dado todo o brilho que deram á arte de seu país?

Feliz a mulher que não sente, no fundo do seu cérebro esse ignoto rumor, tropel de ideias e de pensamentos, vertigens de imaginação, que morre onde nasce, intraduzido, como o ruído do mar dentro do caramujo. Feliz a mulher tranquila e forte, que permanece no lugar que a vida lhe destinou, a burguesa risonha, a matrona serena, para qual o espirito filosofico romano escreveo o epitafio de gloria definitiva e incontestada:

"Governou bem a sua casa, fiou lã;"

Em todo o caso é bom dizer ainda, é bom dizer muitas vezes porque há quem não acredite: a artista não è uma desertora do Lar. Entre todas as rivais que este possa ter, a arte è com certeza a mais pura e a menos perigosa. Pintando, escrevendo ou esculpindo, a mulher necessita exatamente de fechar-se no remanso da sua casa, entre objetos que lhe sejam familiares, na fidelidade das coisas a que se habituou e ás quais se afeiçoa como com participantes do seu labor e como testemunhas do seu sofrimento ou do seu entusiasmo.

Fiando ou tecendo, os dedos trabalham mas a imajinação vagabunda está livre para a construção de enredos pessoais ou a 
criação de devaneios. Pintando esculpindo ou escrevendo dedos e cabeça estão escravisados á mesma ideia, absorvidos pelo mesmo esforço, mais combatido mas muito menos perigoso...

Só por tecer e não fazer mais nada, transmitiu-nos a historia o nome de Penélope, mulher de Ulisses, que a Odisseia tornou símbolo da fidelidade conjugal. Sem querer despretegiar essa figura lendaria tantas vezes evocada, como exemplo, penso que se essa senhora com o tempo que dispunha e aquela paciencia de que deu prova, destramando á noite o que tecera pela manhã, melhor perpetuaria a sua esperança se nessa trama procurasse reproduzir alguma ideia original e de longo desenvolvimento. Suavisaria assim com os elevos da arte a sua viuvez temporaria e teria criado alguma coisa...

O contrario foi viver para traz. Não basta trabalhar para encher as horas, e iludir o tempo, é preciso que esse trabalho seja de algum modo util a si e aos outros e em nenhum dia a mulher compreendeu isto tão bem como no actual em que, a mais essencialmente mulher é pratica e ao mesmo tempo apta para a penetração desse sentimento de infinita doçura que está derramado em todo o ambiente em que nos agitamos. Vós bem o sentis quando olhais pela janela aberta para os fulgores azuis do mar, para o recorte violaceo das montanhas, ou para a estrela solitaria desabrochando ao cair da noite no nosso ceu tropical! Vós bem a sentis, quando vêdes dormir uma criança, lêdes um verso ou murmurais uma prece... Esse não sei quê, que vos sobe aos lábios num sorriso ou aos olhos numa lagrima, esse não sei que, que vos faz sonhar e esquecer o que a vida tem de amargo, é a essencia desse perfume misterioso que anda no ar, a poesia, alma da arte!

Ha naturesas sensiveis, cérebros impressionaveis que procuram dar corpo, tornar visivel esse aroma irradio... São os artistas felizes se conseguem cristalisa-los no seu pensamento, desesperados se o sentem fugir dentre as mãos incapazes. Seja como fôr, a arte é a fascinação das almas felizes ou doloridas, ela não perverte, redime, é o gesto de paz que fraternisa os homens, torre eburnea erguida muito alto no espinhento campo dos pecados.

Bemdita seja!

RECEBIDO EM: 01/08/2018

APROVADO EM: 01/08/2018 